\title{
The Impact of Textual Input Enhancement on Iranian Elementary EFL learners' Vocabulary Intake
}

\author{
Naemeh Nahavandi ${ }^{1} \&$ Jayakaran Mukundan ${ }^{1}$ \\ ${ }^{1}$ Department of Language and Humanities Education, Faculty of Educational Studies, Universiti Putra Malaysia, \\ Malaysia
}

Correspondence: Jayakaran Mukundan, Department of Language and Humanities Education, Faculty of Educational Studies, Universiti Putra Malaysia, 43400 UPM Serdang, Selangor, Malaysia. Tel: 12-209-9717. Fax: 60-38-943-5386. E-mail: jayakaranmukundan@yahoo.com

Received: August 28, 2014 Accepted: September 2, 2014 Online Published: October 30, 2014

doi:10.5539/ass.v10n21p216 URL: http://dx.doi.org/10.5539/ass.v10n21p216

\begin{abstract}
Nowadays, there has been a lot of emphasis on L2 vocabulary learning in the language teaching curriculum. Due to the emergence and prevalence of growing methods in the area of second language teaching, lots of researchers have tried to take advantage of these methods in enhancing L2 learning vocabulary. Thus, the present study investigated the effect of textual input enhancement as a focus on form method on Iranian EFL learners' vocabulary intake from reading. Ninety one elementary EFL learners in Tabriz Azad University participated in a study for eight sessions. A quasi-experimental design with a randomized control and an experimental group was used. Both groups were given five reading texts and comprehension questions to complete. While the participants in experimental group read the textually enhanced input through bolding, the participants in the control group read the same texts without input manipulation. Multiple-choice recognition tests were used to measure the intake of vocabulary. The results showed a significant difference between control and experimental group. The study concluded with some pedagogical implications.
\end{abstract}

Keywords: textual input enhancement, vocabulary intake, Iranian Elementary EFL learners

\section{Introduction}

Vocabulary is not only one important component of language system but also a part of the language competence which is necessary for communication. For Birnjandi, Mosallanezhad \& Bagheridoust (2003) vocabulary cannot be taught but it can be presented and then learned by the learners. For some researchers (Knight, 1994, Schmitt, 2008) vocabulary learning is the most important aspect of second language learning and a necessary part to master a second language. For Wilkins (1972) without grammar very little is conveyed, while without vocabulary nothing is conveyed. For some researchers (Nagy \& Herman, 1987; Sternberg, 1987) incidental vocabulary intake from reading is a major mode of vocabulary acquisition in a first language. For some other researchers (Hulstijn, 2001; Karp, 2002; Krashen, 1989; Pulido, 2007; Prichard, 2008; Schmitt, 2008; Waring \& Takaki, 2003; Webb, 2008; Zhang, 2001) it is the same about second language learning agreeing on the idea that second language learners might gain knowledge of meaning through reading incidentally. In the vocabulary acquisition literature, incidental learning has often been defined as the accidental learning of vocabulary without any intention of learning it. To put it in other words, it is a process that occurs naturally, during reading, when the learner's attention is focused on overall text comprehension. However, it has been claimed that incidental vocabulary learning through reading is not always effective (Laufer, 2003), resulting in small gains of vocabulary presented only in reading texts without any explicit attention on them (Min, 2008) as learners usually fail to notice unfamiliar words, especially while they are dealing with the global message of the text without knowing those words. For Schmidt $(1993,2001)$ such small gains can be attributed to lack of noticing. Schmidt (1995) stats that conscious attention is essential for learning to take place with noticing being the first stage of learning.

In Iranian context, the most frequent way of vocabulary instruction includes first pronouncing the new word, followed by its defining and spelling and finally through explaining new words' grammatical functions which has been proved ineffective by many EFL teachers (Zoghi \& Mirzaei, 2014). Thus, presenting vocabulary through lists of unknown words with their L1 equivalents in a passive manner does not lead to any beneficial 
consequence. Since 1980s or so, visual input enhancement studies have been conducted to achieve the goal of teaching 12 morphosyntax implicitly, mainly through reading activities almost to the exclusion of 12 vocabulary (Cho, 2010; Combs, 2008; Gascoigne, 2006; Kelly, 2008; Lee, 2007; Lee \& Haung, 2008; Mueller, 2010; Nahavandi \& Mukundan, 2013; Rezvani, 2011; Sarkhosh, 2012; Simard, 2009; Song, 2007; Wong, 2005). Nowadays, a shift of interest from the teacher to the learner (Nahavandi, 2011; Nahavandi \& Mukundan, 2012) as well as shift of focus from product oriented learning to process oriented one (Nahavandi, 2013; Nahavandi \& Mukundan, 2013a, Nahavandi \& Mukundan, 2013b; Nahavandi \& Mukundan, 2013c; Nahavandi \& Mukundan, 2014a; Nahavandi \& Mukundan, 2014b) has put more responsibilities on the learners' shoulders. In summary, most of the conducted researches in the area of TE have been on grammatical forms, reporting a small-sized positive effect, but different researchers have come to different conclusions on the effectiveness of such implicit type of teaching method. Therefore, due to the wide discrepancies in methodological features, reliable comparison across studies has been an extremely difficult task (Nahavandi \& Mukundan, 2013d). As such, because of contradictory results, more research in this area especially in EFL context seemed necessary.

\section{Literature Review}

\subsection{Noticing Hypothesis}

Recently, the role of conscious processes has occupied a central place in every second language acquisition (SLA) research, focusing on the Noticing Hypothesis of Schmidt $(1993,2001)$ which has been adopted by a large and probably growing number of researchers. For Schmidt (1994) questions related to the role of consciousness in second language (L2) learning are necessary to practical concerns in applied linguistics, involving the appropriateness of grammar instruction techniques in language pedagogy ranging from attention focusing devices to decontextualized explanations of grammar, as well as to attempts to construct theories of SLA. Schmidt continues to claim that questions related to the role of conscious and unconscious processes in applied linguistics are also connected to current discussions in experimental psychology, linguistics, connectionist modeling, and other disciplines of cognitive science, as well as philosophy. Schmidt (1990) emphasizes the importance of conscious processes but he does not deny the contribution of unconscious processes in the interlanguage development. In his Noticing Hypothesis, he suggests that "subliminal language learning is impossible, and that noticing is the necessary and sufficient condition for converting input into intake" (Schmidt 1990, p. 129). He continues to claim that this requirement of noticing can apply equally to all aspects of language whether lexicon, phonology, grammatical form, or pragmatics, meaning some kind of noticing has to happen in advance in order to learn from input. However, he claims that noticing must not be equated with acquisition, as it only facilitates the process. In addition, Schmidt (1995) claims that, structures of the target language in the input can become more salient through instruction so the likelihood of noticing these structures can increase as well.

\subsection{Textual Input Enhancement (TIE)}

O'Bryan (2004) claims that three ways of TIE or textual input manipulation are 1) making linguistic characteristics salient (typographical or textual enhancement), 2) providing elaborated input, and 3) providing modified input, with TIE being the most major type of input enhancement. For Chapelle (2003) the use of repetition of marked input which is also called typographical input enhancement can make the input more salient For Doughty and William (1998) the basic method of TIE includes increasing the perceptual salience of the target form through using a combination of various formatting techniques such as bolding, underlining of target forms and capitalizing. Urano (2000) having the same idea with Doughty and William (1998) claims that TIE is the written mode of input where the intended target is highlighted; italicized; bolded, or the combination of these techniques is used.

Visual or textual input enhancement (TIE) is based upon the idea that mere exposure to certain 12 structures is insufficient for language acquisition or a mastery of SL to occur (Smith, 1993). Lightbrown and Spada (1990) claim that, it is possible that the 12 learners fail in perceiving certain structures in naturalistic input even after undergoing long exposure to them. In other words, the input does not become intake. Furthermore, Widdowson (1990) claims, when learners are left to their own resources they "do not very readily infer knowledge of the language system from their communicative activities" (p.167). TIE involves highlighting special features of input that may go unnoticed under normal circumstances through typographically manipulating them (Nahavandi \& Mukundan, 2013d). Therefore, based on the main objective of the study which was enhancing learners' vocabulary knowledge, the present study aimed at understanding if TIE as an implicit method of teaching would bring about any changes in Iranian elementary EFL learners vocabulary knowledge or not. To address some of the gaps in the existing literature reviewed above, the present study tries to examine: 
1. Whether textual input enhancement can affect Iranian elementary EFL learners' vocabulary intake or not.

\section{Methodology}

\subsection{Design of the Study}

The present study employed a quasi- experimental design with pretest, treatment, and posttest design. After the pre-test the participants were randomly assigned to the treatment and control group. The participants in the treatment group read the textually enhanced input, while the control group read the same texts without any input manipulation. Each treatment session lasted for about 70 minutes. A post test was given in the last treatment session lasting 30 minutes.

\subsection{Participants}

102 elementary EFL learners in Azad university of Tabriz, Iran registering in General English course during July 2012 participated in a study for eight sessions. The age range of participants who were both male and female students was from 19 to 26 with the average mean of 19.7. In order to make sure that the participants were all at the same level of proficiency regarding their vocabulary knowledge, Cambridge Placement Test of Vocabulary, was administered. The results didn't show a significant difference between two groups. Furthermore, to ascertain that the words were completely new for them, a researcher made test including 30 recognition tests were given to both groups. The results of the pre-test revealed no significant difference between these groups as well. After the pre-test the participants in class $1(\mathrm{~N}=50)$ were assigned to a control group, and participants in class $2(\mathrm{~N}=52)$ to experimental group. The division was done randomly. However, 11 students who were not present in all treatment sessions and posttest session were eliminated from the population pool. Thus, the results of only 91 students, control group (46) and experimental group (45) have been reported here.

\subsection{Instruments}

\subsubsection{Demographic Questionnaire, Reading Texts \& Multiple-Choice Recognition Tests}

In order to obtain necessary demographic information about the participants such as gender, age, educational level, and major of study first a demographic questionnaire was given along the pre-test in the first session. Then, five reading comprehension passages consisting 270 words from Active skills for reading (1) were selected. The participants in the experimental groups read the text with some highlighted words. However, participants in the control group read the same texts in plain. Furthermore, in order to check the students' intake of vocabulary both in pre and posttests multiple-choice recognition tests were used. The reason for using this kind of tests was based on (Leow, 1997; Overstreet, 1998; Nahavandi \& Mukundan, 2013d) who ascertained the effectiveness of these kinds of tests in exploring the impact of TE on intake. First, two researcher made parallel versions of a multiple-choice recognition test namely as (A \& B), one for pretest and one for posttest, with 30 questions each scoring 1 were developed. Besides, In order to ascertain the equality of these two sets, a pilot study was conducted in which all questions of pretest and posttest (60 questions) were put together into one test with even numbers being assigned to pretest questions and odd numbers to posttest questions. Worthy of noting that, with the face validity of the tests being checked by two lecturers of Tabriz Azad University, the new test was administered to one elementary class (30 students) of EFL learners with similar characteristics as those of the target groups at Jahad-e- Daneshgahi institute. In this phase of the study the poor items were either revised or replaced by better items. In order to check the reliability, Cronbach's alpha test was used. The results of the pilot tests indicated reliability indices of 0.792 .

\subsection{Data Analysis}

In the present study, the independent variable was the instructional method while the dependent variable was the participants' intake of vocabulary. The design to carry out this study was a quasi-experimental, with a pretest, different treatments for experimental and control groups, as well as a post-test. Independent and paired t-test were used to answer the research question regarding the difference between two different instructions. The obtained results in the present study were analyzed by SPSS version (20). From 91 students, 58 (63.7) were male, and 33 (36.3) were females. The age range of participants was from 19 to 26 with average mean of 19.7.

\section{Results of the Study}

\subsection{Test of Normality}

Kolmogorov-Smirnov test was used to test the normality of the distribution of the data. The results indicated a normal distribution of the scores at both levels of pretest, and posttest (Significant level $>0 / 05$ ). 
Table 1. One-Sample Kolmogorov-Smirnov Test

\begin{tabular}{cccc}
\hline & $\mathrm{N}$ & Kolmogorov-Smirnov Z & Asymp. Sig. (2-tailed) \\
\hline pre & 91 & 1.072 & .201 \\
post & 91 & .864 & .445 \\
\hline
\end{tabular}

\subsection{Comparing Pretest in Both Groups}

Based on the obtained results parametric statistics was used. First mean score and SD of both groups were calculated.

Table 2. Results of Independent t-test for pre-test in both groups

\begin{tabular}{|c|c|c|c|c|c|c|c|c|c|}
\hline & \multirow{2}{*}{ group } & \multirow[t]{2}{*}{$\mathrm{N}$} & \multirow[t]{2}{*}{ Mean } & \multirow{2}{*}{$\begin{array}{c}\text { Std. } \\
\text { Deviation }\end{array}$} & \multicolumn{2}{|c|}{$\begin{array}{c}\text { Levene's Test for } \\
\text { Equality of Variances }\end{array}$} & \multicolumn{3}{|c|}{$\begin{array}{l}\text { t-test for Equality of } \\
\text { Means }\end{array}$} \\
\hline & & & & & $\mathrm{F}$ & Sig. & $\mathrm{t}$ & $\mathrm{df}$ & Sig. (2-tailed) \\
\hline \multirow{2}{*}{ pre } & control group & 46 & 8.478 & 4.246 & \multirow{2}{*}{.072} & \multirow{2}{*}{.789} & \multirow{2}{*}{.509} & \multirow{2}{*}{89} & \multirow{2}{*}{.612} \\
\hline & experimental group & 45 & 8.933 & 4.287 & & & & & \\
\hline
\end{tabular}

As it can be seen in table 2, mean of control group is 8.478, and experimental group is 8.933. As mean score of experimental group is higher than control group, Levene Statistic test was run to see whether the difference in mean score in these two groups is significant or not. Based on the significant level of Levene test 0/789 $>0 / 05$, homogeneity of variances is confirmed. As the level of significance is $0 / 612>0 / 05$; it can be concluded that there is no significant difference between the groups in pretest. Therefore, it can be claimed that any change in the posttest is unlikely to be the effect of preexisting differences between the groups and, instead, can be attributed to the different treatments that the these groups experienced.

\subsection{Comparing posttest in both groups}

Table 3. Results of Independent t-test for post-test in both groups

\begin{tabular}{|c|c|c|c|c|c|c|c|c|c|}
\hline & \multirow{2}{*}{ group } & \multirow{2}{*}{$\mathrm{N}$} & \multirow{2}{*}{ Mean } & \multirow{2}{*}{$\begin{array}{c}\text { Std. } \\
\text { Deviation }\end{array}$} & \multicolumn{2}{|c|}{$\begin{array}{c}\text { Levene's Test for } \\
\text { Equality of Variances }\end{array}$} & \multicolumn{3}{|c|}{ t-test for Equality of Means } \\
\hline & & & & & $\mathrm{F}$ & Sig. & $\mathrm{t}$ & df & $\begin{array}{c}\text { Sig. } \\
\text { (2-tailed) }\end{array}$ \\
\hline post & $\begin{array}{c}\text { control group } \\
\text { experimental group }\end{array}$ & $\begin{array}{l}46 \\
45\end{array}$ & $\begin{array}{l}9.456 \\
13.33\end{array}$ & $\begin{array}{l}4.183 \\
4.940\end{array}$ & 1.691 & .197 & 4.043 & 89 & .000 \\
\hline
\end{tabular}

In order to compare post tests in both groups, independent t-test was used. As it can be seen in table 3, mean of control group is 9.456 , and experimental group is 13.33 with the level of significance of .000 . As the level of sig is smaller than $0.05,0.05>.000$ it can be concluded that there is a significant difference between experimental and control groups in the post test. It means that experimental group significantly outperformed the control group in the post test.

\section{Discussion \& Conclusion}

Decontextualized vocabulary training makes vocabulary learning a dull and extremely difficult task for learners. Therefore, if teachers try to employ contextualized materials for teaching vocabulary, rather than presenting it in isolation, the lexical items can be maintained much longer in learners' minds (Zoghi \& Mirzaei, 2014). For some researchers (Mitchell, 2000; Williams, 2005, Ellis, 2006) TIE has attracted lots of attention in Second Language (SL) literature in the light of classroom research that supports the need for pedagogical interventions to push learners towards higher levels of proficiency in 12. For Sharwood Smith (1991) TIE helps learners in noticing certain linguistic forms in the input that have been forgotten or ignored. Elsewhere he claims that TIE help learners in input to intake process as it underlines linguistic forms which usually go unnoticed (1993). For many researchers, the enrichment of the context in which language learning takes place, might have great impact on learners' development of vocabulary (Read, 2004). In TE vocabulary learning occurs incidentally not because the learner is trying to learn the new words but because the learner is trying to understand the meaning of the 
context. The results of the present study indicated a positive effect of TIE on vocabulary intake with the experimental group outperforming the control group significantly.

Based on the results of the present study some pedagogical implications can be made. Teachers can increase 12 learners' vocabulary learning through reading enhanced texts. As intentional learning requires more effort, energy and, motivation on the part of 12 learners, and time, it seems necessary that teachers and material developers provide materials that the learners consider relevant and interesting and easy to learn and remember. The present research may encourage other interested researchers to do further research in the area of TE among EFL learners. However, worthy of noting that caution must be taken while interpreting the results of the present study or trying to make generalizations of the findings to larger populations in Iran or to other populations with different ethnic, linguistic, or educational backgrounds as the present study was conducted with only 109 elementary EFL engineering students.

\section{References}

Birnjandi, P., Mosallanezhad, P., \& Bagheridoust, E. (2003). Principles of teaching foreign languages. Rahrovan publication.

Chapelle, C. (2003). English language teaching and technology. Philadelphia: J. Benjamins Publishing Company.

Cho, M. Y. (2010). The effects of input enhancement and written recall on noticing and acquisition. Innovation in Language Learning and Teaching, 4(1), 71-87. http://dx.doi.org/10.1080/17501220903388900

Combs, Ch. (2008). Topic familiarity and Input Enhancement: An empirical investigation. TESOL \& Applied Linguistics, $8(2)$.

Doughty, C., \& Williams, J. (1998). Focus on form in classroom second language acquisition. Cambridge University Press.

Ellis, R. (2006). Current issues in the teaching of grammar: An SLA perspective. TESOL Quarterly, 40(1), 83-107. http://dx.doi.org/10.2307/40264512

Hulstijn, J. H. (2001). Intentional and incidental second-language vocabulary learning: A reappraisal of elaboration, rehearsal and automaticity. In P. Robinson (Ed.), Cognition and Second Language Instruction (pp. 349-381). Cambridge University Press. http://dx.doi.org/10.1017/CBO9781139524780.011

Karp, A. S. (2002). Modification of glosses and its effect on incidental L2 vocabulary learning in Spanish. Unpublished doctoral dissertation, University of California, Davis.

Kelly, G. P. B. R. R. (2008). The Efficacy of Visual Input Enhancement in Teaching Deaf Learners of L2 English. Understanding second language process, 80.

Knight, S. (1994). Dictionary use while reading: The effect on comprehension and vocabulary acquisition for students of different verbal abilities. The Modern Language Journal, 78(3), 285-299. http://dx.doi.org/ 10.1111/j.1540-4781.1994.tb02043.x

Krashen, S. (1989). We acquire vocabulary and spelling by reading: Additional evidence for the input hypothesis. The Modern Language Journal, 73, 440-464. http://dx.doi.org/10.1111/j.1540-4781.1989.tb05325.x

Laufer, B. (2003). Vocabulary acquisition in a second language: Do learners really acquire most vocabulary by reading? Some empirical evidence. The Canadian modern language review, 59(4), 567-587. http://dx.doi.org/10.3138/cmlr.59.4.567

Lee, S. K. (2007). Effects of textual enhancement and topic familiarity on Korean EFL students' reading comprehension and learning of passive form. Language learning, 57(1), 87-118. http://dx.doi.org/ 10.1111/j.1467-9922.2007.00400.x

Lee, S. K., \& Huang, H. T. (2008). Visual input enhancement and grammar learning: A meta-analytic review. Studies in Second Language Acquisition, 30(3), 307-331. http://dx.doi.org/10.1017/S0272263108080479

Leow, R. (1997). The effects of input enhancement and text length on adult L2 readers' comprehension and intake in second language acquisition. Applied Language Learning, 8, 151-182.

Lightbown, P., \& Spada, N. (1990). Focus on form and corrective feedback in communicative language teaching: Effects on second language learning. Studies in Second Language Acquisition, 12, 429-448. http://dx.doi.org/10.1017/S0272263100009517

Min, H.-T. (2008). EFL vocabulary acquisition and retention: Reading plus vocabulary enhancement activities 
and narrow reading. Language Learning, 58(1), 73-115. http://dx.doi.org/10.1111/j.1467-9922.2007. 00435.x

Mitchell, R. (2000). Anniversary article. Applied linguistics and evidence-based classroom practice: The case of foreign language grammar pedagogy. Applied Linguistics, 21(3), 281-303. http://dx.doi.org/10.1093/applin/ 21.3.281

Mueller, C. M. (2010). Effects of Explicit Instruction on Incidental Noticing of Metaphorical Word Sequences during a Subsequent Reading Task. International Journal of English Studies, 10(1), 81-101.

Nagy, W. E., \& Herman, P. A. (1987). Breadth and depth of vocabulary knowledge: Implications for acquisition and instruction. In M. G. McKeown \& M. Curtis (Eds.), The nature of vocabulary acquisition (pp. 19-35). Hillsdale, NJ: Erlbaum.

Nahavandi, N. (2011). The effect of task-based activities on EFL learners' reading comprehension. In J. Mukundan, V. Nimehchisalem, S. Menon, Y. J. Jin, R. Roslim, A. Leong, A. Mohamad, \& A. Philip (Eds.), ELT Matters, 5 (pp. 56-69). Petalingjaya, Malaysia: Galaxy.

Nahavandi, N. (2013). Task-based activities in reading comprehension classes: Task-based language teaching \& learning. LAP Lambert Academic Publishing.

Nahavandi, N., \& Mukundan, J. (2012). Task-based Language Teaching from Teachers' Perspective. International Journal of Applied Linguistics \& English Literature, 1(6), 115-121, http://dx.doi.org/10.7575/ ijalel.v.1n.6p.115

Nahavandi, N., \& Mukundan, J. (2013a). Foreign Language Learning Anxiety among Iranian EFL learners Along Gender \& Different Proficiency Levels. Language in India, 13(1), 133-161.

Nahavandi, N., \& Mukundan, J. (2013b). Iranian EFL Engineering Students' Motivational Orientations towards English Language Learning along Gender and Further Education in Language Institutes. International Journal of Linguistics, 5(1). http://dx.doi.org/10.5296/ijl.v5i1.2684

Nahavandi, N., \& Mukundan, J. (2013c). Task-based cycle in reading comprehension classes. International Journal of Applied Linguistics \& English Literature, 1(6), 115-121. http://dx.doi.org/10.7575/aiac. ijalel.v.2n.2p.107

Nahavandi, N., \& Mukundan, J. (2013d). The Impact of Textual Input Enhancement and Explicit Rule Presentation on Iranian Elementary EFL Learners' Intake of Simple Past Tense. English Language Teaching, 6(1), 92-102. http://dx.doi.org/10.5539/elt.v6n1p92

Nahavandi, N., \& Mukundan, J. (2014a). EFL Learners' Beliefs about Language Learning along Gender, Further Education in Language Institutes \& Different Proficiency Levels. International Journal of Applied Linguistics \& English Literature, 3(1), 170-180. http://dx.doi.org/10.7575/aiac.ijalel.v.3n.1p.170

Nahavandi, N., \& Mukundan, J. (2014b). Language Learning Strategy Use among Iranian Engineering EFL Learners. Advances in Language and Literary Studies, 5(5), 34-45. http://dx.doi.org/10.7575/aiac.alls.v.5n.5 p.34

O’Bryan, A. (2004). Pedagogical point-input enhancement: Introduction. Unpublished doctoral dissertation, State University of Lowa.

Overstreet, M. (1998). Text enhancement and content familiarity: The focus of learner attention. Spanish Applied Linguistics, 2, 229-258.

Prichard, C. (2008). Evaluating L2 readers' vocabulary strategies and dictionary use. Reading in a Foreign Language, 20(2), 219-231.

Pulido, D. (2007). The relationship between text comprehension and second language incidental vocabulary acquisition: A matter if topic familiarity? Language Learning, 57, 155-199. http://dx.doi.org/10.1111/ j.1467-9922.2007.00415.x

Read, J. (2004). Research in teaching vocabulary. Annual Review of Applied Linguistics, 24, 146-161.

Rezvani, A. (2011). The Effect of Output Requirement on the Acquisition of Grammatical Collocations by Iranian EFL Learners. Journal of Language Teaching and Research, 2(3), 674-682. http://dx.doi.org/10.4304/j1tr.2.3.674-682

Sarkhosh, M., \& Sarboland, E. (2012). Different Textual Enhancement Formats and the Intake of English Past Simple Tense. International Journal of Linguistics, 4(2), 459-474. http://dx.doi.org/10.5296/ijl.v4i2.1861 
Schmidt, R, (1990). The role of consciousness in second language learning. Applied Linguistics, 11(2), 129-158.

Schmidt, R. (1995). Consciousness and foreign language learning: A tutorial on the role of attention and awareness in learning. In R. Schmidt. Hawai'I (Ed.), Attention and Awareness in Foreign Language Learning (pp. 1-65). University of Hawai'i, Second Language Teaching and Curriculum Center.

Schmidt, R. (2001). Attention. In P. Robinson (Ed.), Cognition and second language instruction (pp. 3-32). Cambridge: Cambridge University Press.

Schmitt, N. (2008). Review article: Instructed second language vocabulary learning. Language Teaching Research, 12(3), 329-363.

Sharwood Smith, M. (1991). Speaking to many minds: On the relevance of different types of language information for the L2 learner. Second Language Research, 7, 118-132.

Sharwood Smith, M. (1993). Input enhancement in instructed SLA. Studies in Second Language Acquisition, 15 , 165-179.

Simard, D. (2009). Differential effects of textual enhancement formats on intake. System, 37(1), 124-135. http://dx.doi.org/10.1016/j.system.2008.06.005

Song, M. (2007). Getting learners' attention: Typographical input enhancement, output, and their combined effects. English Teaching, 62, 193-215.

Sternberg, R. J. (1987). Most vocabulary is learned from context. In M. G. McKeown, \& M. E. Curtis (Eds.), The nature of vocabulary acquisition (pp. 89-105). Hillsdale, NJ: Erlbaum.

Urano, K. (2000). Lexical simplification and elaboration: Sentence comprehension and incidental vocabulary learning. Unpublished master's thesis, University of Hawai'i, Manoa.

Waring, R., \& Takaki M. (2003). At What rate do learners learn and Retain new vocabulary from reading a graded reader? Reading in a Foreign Language, 15(2), 103-163.

Webb, S. (2008). The effects of context on incidental vocabulary learning. Reading in a Foreign Language, 20(2), 1-4.

Widdowson, H. G. (1990). Aspects of language teaching. Oxford: Oxford University Press.

Williams, J. (2005). Form-focused instruction. In E. Hinkel (Ed.), Handbook of research in second language teaching and learning (pp. 671-692). Mahwah, NJ: Lawrence Erlbaum.

Wong, W. (2005). Input enhancement: From theory and research to the classroom. McGraw-Hill.

Zhang, L. J. (2001). Awareness in reading: EFL students' metacognitive knowledge of reading strategies in an acquisition-poor environment. Language Awareness, 10, 268-288. http://dx.doi.org/10.1080/0965841 0108667039

Zoghi, M., \& Mirzaei M. (2014). A Comparative Study of Textual and Visual Contextualization on Iranian EFL Learners' Vocabulary Learning. International Journal of Basic and Applied Science, 2(3), 31-40.

\section{Copyrights}

Copyright for this article is retained by the author(s), with first publication rights granted to the journal.

This is an open-access article distributed under the terms and conditions of the Creative Commons Attribution license (http://creativecommons.org/licenses/by/3.0/). 